\title{
AN EXPERIMENTAL INVESTIGATION OF THE IMPACT
}

\section{OF NANOPARTICLES ON THE TRIBOLOGICAL}

\section{PROPERTIES OF 15W40 LUBRICATING OIL}

\section{SUMIT CHAUDHARY, RAMESH CHANDRA SINGH \& RAJIV CHAUDHARY}

Department of Mechanical Engineering, Delhi Technological University, Delhi, India

\section{ABSTRACT}

The objective of this research is to investigate the effect of various nanoparticles $\left(\mathrm{SiO}_{2}, \mathrm{WS}_{2}, \mathrm{Cu}, \mathrm{CuO}\right.$ and graphite) on the tribological properties of 15 W40 Lubricating oil. The nanoparticles blended in the lubricant homogenously using magnetic stirring and ultrasonication, surfactant was used in the case of $\mathrm{Cu}$ and $\mathrm{CuO}$ nanoparticles to enhance the stability of nanolubricant. The tribological testing of the nanolubricant was carried out on four ball tester according to ASTM- D4172 for wear preventive characteristics of the lubricant and ASTM- DIN 5135002 for extreme pressure test of liquid lubricant. The experimental analysis showed that the coefficient of friction (COF) and wear scar diameter (WSD) reduced by using the nanoparticles in the lubricant. The reduction of COF is maximum in case of $\mathrm{SiO}_{2}$ nanolubricant $15 \%-25 \%$ followed by graphite nanolubricant $\approx 15 \%-18 \%$, WS 2 nanolubricant $\approx 13 \%-21 \%$ and $\mathrm{Cu}$ nanolubricant $\approx 9 \%-20 \%$, CuO showed minimum reduction in $\mathrm{COF} \approx 1.5 \%-17 \%$. The reduction in WSD in case

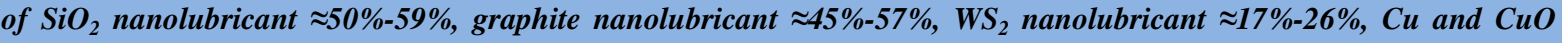
showed $\approx 33 \%-49 \%$ and $\approx 13 \%-28 \%$ respectively. The percentage increments in the weld load were maximum in case of $\mathrm{CuO}$ nanolubricant $\approx 29 \%$, followed by $\mathrm{WS}_{2}$ nanolubricant $\approx 27 \%$. In case of Cu nanolubricant, SiO $\mathrm{n}_{2}$ nanolubricant, Graphite nanolubricant improvement is about $\approx 22 \%, 11 \%, 19 \%$ respectively.

KEYWORDS: Nanoparticles, Nanolubricant, Tribology, Friction Modifiers, Anti-Wear \& Extreme Pressure Behaviour

Received: Jul 21, 2018; Accepted: Aug 17, 2018; Published: Aug 31, 2018; Paper Id.: IJMPERDOCT201822

\section{INTRODUCTION}

Effort has been made to develop advanced lubricating oil to improve the tribological properties of the tribopair and service life. The introduction of nanoparticles makes them promising contender as it possess better physical and chemical properties than the base material. The nanoparticles blended in lubricating oil emerged as new tool for improving the tribological properties and service life of the lubricant.

When the dimensions of any material got reduced to nano level, a significant change appears in the physical, chemical and mechanical properties as compared to the bulk material. The 2D structure and reduced grain size of nanoparticles enables large surface area to volume ratio, large surface energy, high hardness and high toughness [1].

The lubricant serves the prime function of reducing friction by avoiding material to material contact, it also provides an atmospheric insulation to the material [2]. The majority of the lubricants have about $90 \%$ of hydrocarbons rest is organic phosphorus and sulfide compounds used as a performance booster for the lubricant. The nanoparticles may prove to be the correct replacement of the harmful lubricant additives as they reduce 
friction and wear, and provide high extreme pressure performance of the lubricant [3-6] The tribological properties enhancement by the use of nanoparticles in the lubricant as additives $\sim 2 \% \mathrm{w} / \mathrm{w}$ may be due to; rolling effect provided by the nanoparticles as the tribopair interface resulting in low friction and wear, low melting point melts and get deposited in the tribopair surface resulting in the reduction of friction and wear, nanoparticles may enter the cracks on the surface of tribopair, reduces friction and wear. The blending of solid particles (nanoparticles) increases extreme pressure properties of the lubricant [7-11]. Copper nanopowder in lubricating oil produced in-situ thin layer over the tribopair hence reduces friction at higher loads and higher sliding speeds [12-14]. Graphite nanosheets blended with paraffin oil $\left(1.0 \times 10^{-2} \mathrm{wt} \%\right)$ tested on four ball tester improved tribological and extreme pressure performance of paraffin [15]. Nanoparticles of $\mathrm{SiO}_{2}$ blended in 15W40 lubricating oil was rheologicaly stable and improved anti-wear and anti-friction property of $15 \mathrm{~W} 40$ lubricating oil [16,17]. $\mathrm{WS}_{2}$ nanoparticles added to paraffin and SA 90 lubricating oil showed significant decrement in wear and friction force got reduced 50\% [18]. CuO nanoparticles blended in the lubricant showed 273\% improvement in load carrying capacity and slight improvement in the tribological properties due to formation of tribo-sintered layer of $\mathrm{CuO}$ over the tribopairs $[19,20]$

It has been observed from the literature that the blending of nanoparticles in the lubricant showed significant decrement in wear and friction, moreover improved the service life of the lubricant. Hence the nanoparticles may be used as lubricant blenders to produce advanced lubricant. Thus the objective of this study is to produce a stable nanolubricant and investigate the influence of various nanoparticles $\left(\mathrm{SiO}_{2}, \mathrm{WS}_{2}, \mathrm{Cu}, \mathrm{CuO}\right.$ and graphite) on the tribological properties of 15W40 Lubricating oil.

\section{EXPERIMENTAL SETUP}

The experimentation started with blending of nanoparticles in the 15W40 lubricating oil, the magnetic stirrer and Ultrasonicator were used for blending. The tribological testing was carried out on four ball tester and the wear scar diameter was measured using optical microscope.

\section{Preparation of Nanolubricant}

The nanolubricants had been prepared by blending the nanoparticles of graphite, $\mathrm{Cu}, \mathrm{CuO}, \mathrm{SiO}_{2}$ and $\mathrm{WS}_{2}$ in 15W40 lubricating oil. The blending techniques used for producing the nanolubricant and the stability are as shown in the Table 1.

Table 1: Preparation and Stability of Nanolubricant

\begin{tabular}{|c|c|c|c|c|}
\hline Nanoparticles & $\begin{array}{l}\text { Base } \\
\text { Fluid }\end{array}$ & Surfactant & $\begin{array}{c}\text { Blending } \\
\text { Technique } \\
\end{array}$ & $\begin{array}{c}\text { Stability of } \\
\text { Nanolubricant }\end{array}$ \\
\hline $\begin{array}{l}\text { Graphite } \\
\text { Nanoparticles }\end{array}$ & $15 \mathrm{~W} 40$ & - & $\begin{array}{l}\text { Stirring for } 2 \text { hours } \\
\text { at } 70^{\circ} \mathrm{C} \text { and } 2000 \\
\text { rpm and then } \\
\text { untrasonication at } \\
20 \mathrm{kHz}, 400 \mathrm{~W} \text { full } \\
\text { pulse for } 60 \\
\text { minutes. }\end{array}$ & $\begin{array}{l}\text { The } \\
\text { nanolubricant } \\
\text { showed no } \\
\text { sedimentation } \\
\text { after } 30 \text { days of } \\
\text { blending. }\end{array}$ \\
\hline $\begin{array}{l}\mathrm{SiO}_{2} \\
\text { Nanoparticles }\end{array}$ & $15 \mathrm{~W} 40$ & - & $\begin{array}{l}\text { Stirring for } 2 \text { hours } \\
\text { at } 70^{\circ} \mathrm{C} \text { and } 2000 \\
\text { rpm and then } \\
\text { untrasonication at } \\
20 \mathrm{kHz}, 400 \mathrm{~W} \text { full } \\
\text { pulse for } 3 \text { hours. }\end{array}$ & $\begin{array}{l}\text { The } \\
\text { nanolubricant } \\
\text { showed no } \\
\text { sedimentation } \\
\text { after } 30 \text { days of } \\
\text { blending }\end{array}$ \\
\hline
\end{tabular}




\begin{tabular}{|c|c|c|c|c|}
\hline \multicolumn{5}{|c|}{ Table 1: Contd., } \\
\hline $\begin{array}{l}\mathrm{Cu} \\
\text { Nanoparticles }\end{array}$ & $15 \mathrm{~W} 40$ & CTAB & $\begin{array}{l}\text { Stirring for } 2 \text { hours } \\
\text { at } 70^{\circ} \mathrm{C} \text { and } 2000 \\
\text { rpm and then } \\
\text { untrasonication at } \\
20 \mathrm{kHz}, 400 \mathrm{~W} \text { full } \\
\text { pulse for } 6 \text { hours in } \\
\text { succession of } 1 \\
\text { hour. }\end{array}$ & $\begin{array}{l}\text { The } \\
\text { nanolubricant } \\
\text { showed } \\
\text { sedimentation } \\
\text { after } 15 \text { days of } \\
\text { blending }\end{array}$ \\
\hline $\begin{array}{l}\mathrm{CuO} \\
\text { Nanoparticles }\end{array}$ & $15 \mathrm{~W} 40$ & CTAB & $\begin{array}{l}\text { Stirring for } 2 \text { hours } \\
\text { at } 70^{\circ} \mathrm{C} \text { and } 2000 \\
\text { rpm and then } \\
\text { untrasonication at } \\
20 \mathrm{kHz}, 400 \mathrm{~W} \text { full } \\
\text { pulse for } 6 \text { hours in } \\
\text { succession of } 1 \\
\text { hour. }\end{array}$ & $\begin{array}{l}\text { The } \\
\text { nanolubricant } \\
\text { showed } \\
\text { sedimentation } \\
\text { after } 19 \text { days of } \\
\text { blending }\end{array}$ \\
\hline $\begin{array}{l}\mathrm{WS}_{2} \\
\text { Nanoparticles }\end{array}$ & $15 \mathrm{~W} 40$ & - & $\begin{array}{l}\text { Stirring for } 2 \text { hours } \\
\text { at } 70^{\circ} \mathrm{C} \text { and } 2000 \\
\text { rpm and then } \\
\text { untrasonication at } \\
20 \mathrm{kHz}, 400 \mathrm{~W} \text { full } \\
\text { pulse for } 8 \text { hours in } \\
\text { succession of } 60 \\
\text { minutes. }\end{array}$ & $\begin{array}{l}\text { The } \\
\text { nanolubricant } \\
\text { showed no } \\
\text { sedimentation } \\
\text { after } 30 \text { days of } \\
\text { blending }\end{array}$ \\
\hline
\end{tabular}

\section{Tribological Testing}

The tribological testing for the prepared nanolubricant had been carried out on four ball tester according to ASTM- DIN 51350 for extreme pressure and ASTM- D4172 for friction and wear characteristics of the lubricating oil.

In the four ball tester the load is applied from vertically downward direction. The upper ball rotates with constant rpm. The temperature of the assembly is maintained at the desired value by temperature controlled unit. The value of frictional torque of the experiment is directly measured by using a load sensor, which helps in calculating the coefficient of friction.

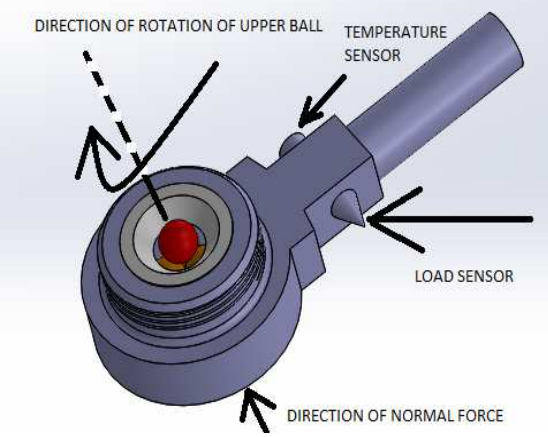

Figure 1: Four Ball Tester Schematic 
Table 2: Parameters of Four Ball Tester

\begin{tabular}{|l|l|l|}
\hline \multicolumn{1}{|c|}{ Parameters } & \multicolumn{1}{|c|}{ Wear Test } & \multicolumn{1}{c|}{$\begin{array}{c}\text { Extreme } \\
\text { Pressure Test }\end{array}$} \\
\hline ASTM & ASTM- D4172 & $\begin{array}{l}\text { ASTM- DIN } \\
51350-02\end{array}$ \\
\hline Ball Specimen & $\begin{array}{l}\text { Steel Balls, } \\
\text { Diameter 12.7 mm, } \\
\text { Ra=0.04 microns, } \\
\text { Hardness RC 65 }\end{array}$ & $\begin{array}{l}\text { Steel Balls, } \\
\text { Diameter 12.7 } \\
\text { mm, Ra=0.04 } \\
\text { microns, } \\
\text { Hardness RC 65 }\end{array}$ \\
\hline Oil Specimen & $\begin{array}{l}\text { 15W40 and } \\
\text { with graphite } \\
\text { nanoparticles }\end{array}$ & $\begin{array}{l}\text { 15W40 and } \\
15 W 40 b l e n d e d \\
\text { with graphite } \\
\text { nanoparticles }\end{array}$ \\
\hline $\begin{array}{l}\text { Load } \\
196 \text { N, 392 N, 588 } \\
\text { N }\end{array}$ & $\begin{array}{l}\text { Incremental } \\
\text { Load Starting } \\
\text { from 2000 N }\end{array}$ \\
\hline $\begin{array}{l}\text { Rotational } \\
\text { speed of top } \\
\text { ball }\end{array}$ & $1200 \mathrm{rpm}$ & 1450 rpm \\
\hline Temperature & $75^{\circ} \mathrm{C}$ & Ambient \\
\hline Test Duration & 60 minutes & 60 s \\
\hline
\end{tabular}

\section{RESULTS AND DISCUSSIONS}

In the present analysis the prepared nanolubricants were tested on Four Ball Tester for their performance analysis by measuring coefficient of friction and wear scar diameter and stability was analyzed by means of weld load measurement.

a)

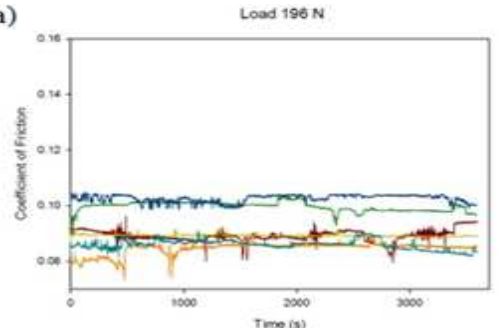

c)

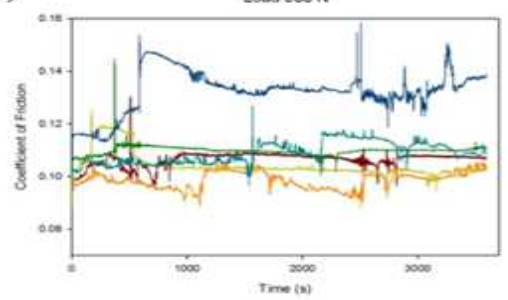

b)
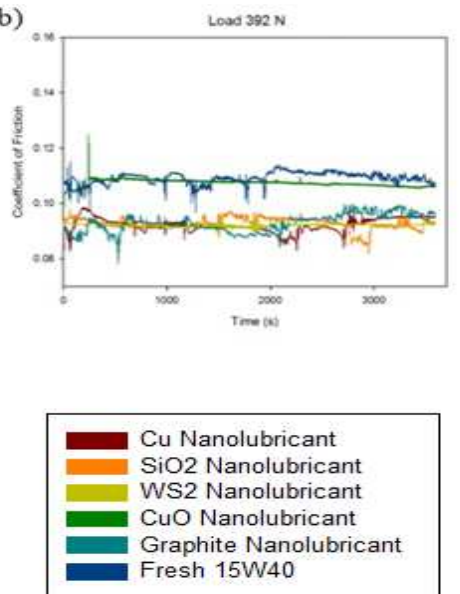

Figure 2: Load v/s Coefficient of Friction in Presence of Various Lubricants a) At Load 196 N, b) At Load 392 N, c) At Load 588 N

\section{Coefficient of Friction}

The experiment was performed on three loads $196 \mathrm{~N}, 392 \mathrm{~N}$ and $588 \mathrm{~N}$. The coefficient of the friction is (COF) increased as the load is increased. The lubricant blended with nanoparticles had lower values of coefficient of friction as compared to the fresh lubricant. Table 3 shows the percentage of decrease in the value of the coefficient of friction as 
compared to fresh15W40 lubricating oil. The nanoparticles of $\mathrm{SiO}_{2}$ blended with $15 \mathrm{~W} 40$ lubricating oil showed 15\% to $25 \%$ decrease in COF. The nanoparticles of graphite showed $\sim 15 \%-18 \%$ decrement in COF. The nanoparticles of $\mathrm{Cu}$ and $\mathrm{CuO}$ showed $\sim 9 \%-20 \%$ and $\sim 1.5 \%$ to $17 \%$ reduction in COF respectively, whereas the nanoparticle of $\mathrm{WS}_{2}$ showed $\sim$ $13 \%-21 \%$ decrease in COF.

Table 3: Percentage Decrease in COF Values in Presence of Nanoparticles in the Lubricant

\begin{tabular}{|l|c|c|c|}
\hline \multirow{2}{*}{ Nano Lubricant } & \multicolumn{3}{|c|}{ Percent Decrease in Coefficient of Friction } \\
\cline { 2 - 4 } & Load 196 N & Load 392 N & Load 588 N \\
\hline $\mathrm{SiO}_{2}$ Nanolubricant & $17.46 \%$ & $15.44 \%$ & $25.55 \%$ \\
\hline Graphite Nanolubricant & $16.23 \%$ & $15.4 \%$ & $17.72 \%$ \\
\hline Cu Nanolubricant & $13.65 \%$ & $9.07 \%$ & $19.6 \%$ \\
\hline $\mathrm{CuO}$ Nanolubricant & $2.78 \%$ & $1.48 \%$ & $17 \%$ \\
\hline $\mathrm{WS}_{2}$ Nanolubricant & $13.64 \%$ & $15.12 \%$ & $21.13 \%$ \\
\hline
\end{tabular}

\section{Wear Scar Diameter}

The wear scar diameter (WSD) was examined for all three loads $196 \mathrm{~N}, 392 \mathrm{~N}$ and $588 \mathrm{~N}$. The Wear scar diameter increased as the load increased. The nanoparticles in the lubricant decreased the Wear scar diameter significantly. Table 4 shows the percentage of decrease in the value of the Wear scar diameter as compared to fresh15W40 lubricating oil. The nanoparticles of $\mathrm{SiO}_{2}$ blended with $15 \mathrm{~W} 40$ lubricating oil showed 50\% to 59\% decrease in WSD. The nanoparticles of graphite showed 45\% - 57\% decrement in WSD. The nanoparticles of $\mathrm{Cu}$ and $\mathrm{CuO}$ showed $\sim 33 \%-49 \%$ and $\sim 13 \%$ to $28 \%$ reduction in WSD respectively, whereas the nanoparticle of $\mathrm{WS}_{2}$ showed $\sim 17 \%-$ $26 \%$ decrease in WSD.

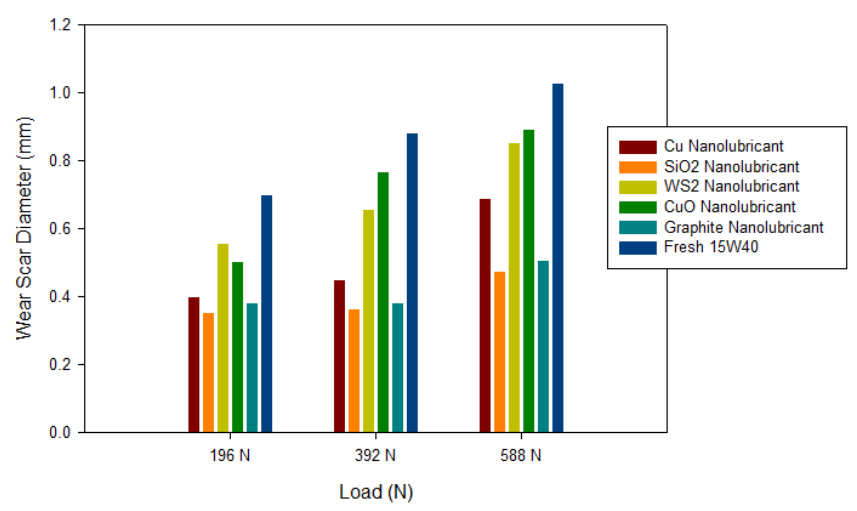

Figure 3: Load v/s Wear Scar Diameter in the Presence of Various Lubricants

Table 4: Percentage Decrease in WSD Values in Presence of Nanoparticles in the Lubricant

\begin{tabular}{|l|c|c|c|}
\hline \multirow{2}{*}{ Nanolubricant } & \multicolumn{3}{c|}{ Percent decrease in Wear Scare Diameter } \\
\cline { 2 - 4 } & Load 196 N & Load 392 N & Load 588 N \\
\hline $\mathrm{SiO}_{2}$ Nanolubricant & $49.64 \%$ & $59.91 \%$ & $54.15 \%$ \\
\hline Graphite Nanolubricant & $45.32 \%$ & $56.82 \%$ & $50.73 \%$ \\
\hline $\mathrm{Cu}$ Nanolubricant & $43.16 \%$ & $49.40 \%$ & $33.17 \%$ \\
\hline $\mathrm{CuO}$ Nanolubricant & $28.06 \%$ & $13.07 \%$ & $13.17 \%$ \\
\hline $\mathrm{WS}_{2}$ Nanolubricant & $20.14 \%$ & $25.57 \%$ & $17.07 \%$ \\
\hline
\end{tabular}


a)

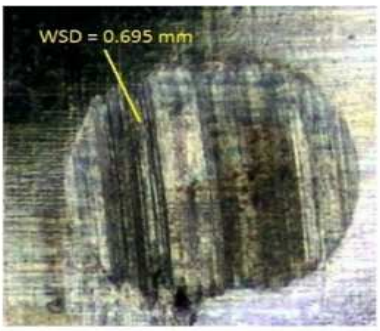

c)
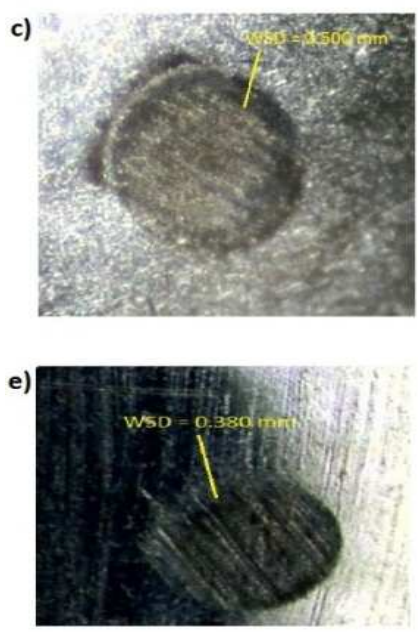

b)

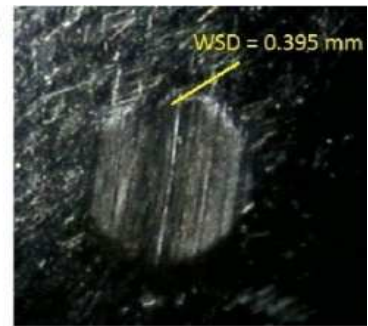

d)

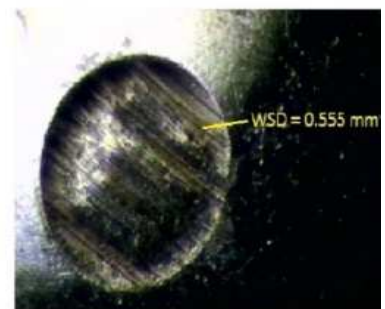

f)

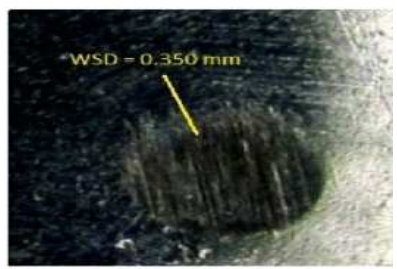

Figure 4: Wear Scar Diameter Observed by Optical Microscope at 196 N a) 15 W40 Lubricant, b) Cu Nanolubricant, c) $\mathrm{CuO}$ Nanolubricant, d) $\mathrm{ws}_{2}$ Nanolubricant, e) Graphite Nanolubricant, f) $\mathrm{SiO}_{2}$ Nanolubricant
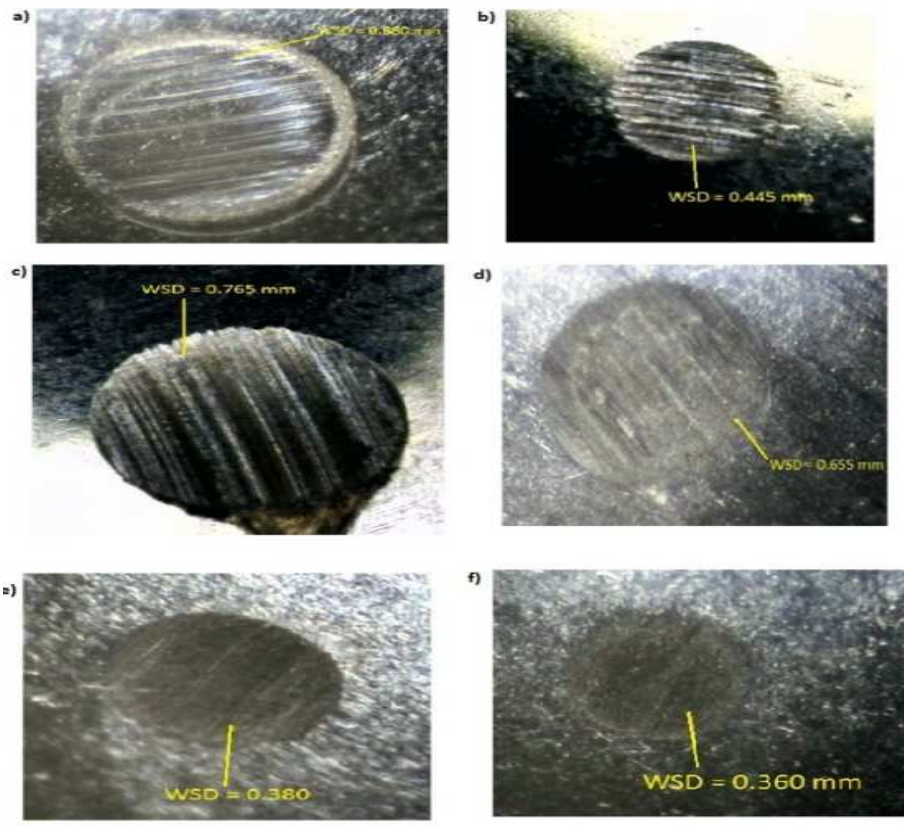

Figure 5: Wear Scar Diameter Observed by Optical Microscope at 392 N a) 15 W40 Lubricant, b) Cu Nanolubricant, c) CuO Nanolubricant, d) $\mathrm{WS}_{2}$ Nanolubricant, e) Graphite Nanolubricant, f) $\mathrm{SiO}_{2}$ Nanolubricant 

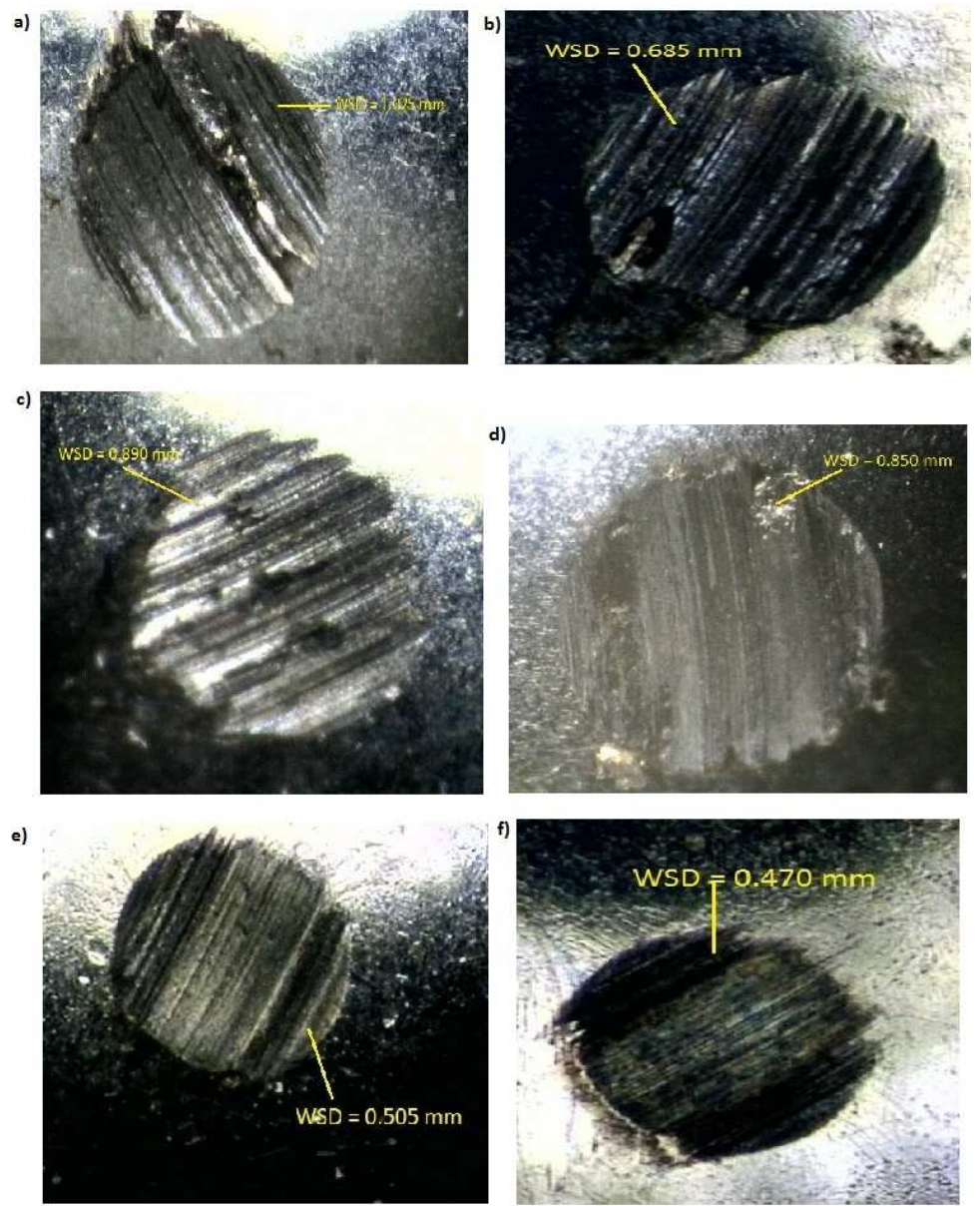

Figure 6: Wear Scar Diameter Observed by Optical Microscope at $588 \mathrm{~N}$

a) 15 W40 Lubricant, b) Cu Nanolubricant, c) CuO Nanolubricant,

d) $\mathrm{WS}_{2}$ Nanolubricant, e) Graphite Nanolubricant, f) $\mathrm{SiO}_{2}$ Nanolubricant.

\section{Extreme Pressure Analysis}

The extreme pressure performance of the prepared nanolubricant was conducted according to ASTM- DIN 51350. The weld load was calculated for each nanolubricant and compared with Fresh 15 W40 lubricating oil. The extreme pressure performance of the nanolubricant showed better results than the fresh $15 \mathrm{~W} 40$ Lubricating oil. The percentage increases in the weld load for $\mathrm{Cu}$ nanolubricant, $\mathrm{SiO}_{2}$ nanolubricant, $\mathrm{WS}_{2}$ nanolubricant, $\mathrm{CuO}$ nanolubricant and Graphite nanolubricant obtained 22\%, 11\%, 27\%, 29\% and 19\% respectively.

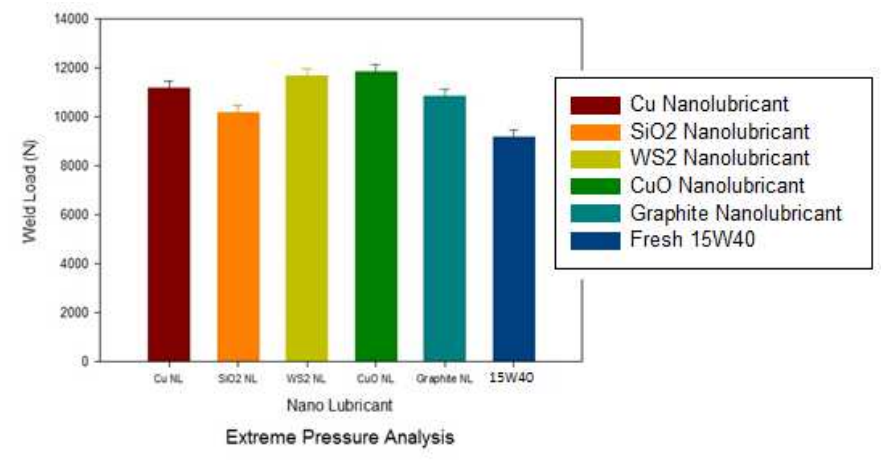

Figure 7: Extreme Pressure Analysis of Lubricants 


\section{CONCLUSIONS}

The nanoparticles were blended homogeneously in 15W40 lubricating oil with the help of mechanical stirring and ultrasonication. In case of $\mathrm{Cu}$ and $\mathrm{CuO}$ nanoparticles, $\mathrm{CTAB}$ was used as surfactant to improve the dispersion and stability.

The antiwear characteristics of the nanolubricant were tested on four ball tester according to ASTM- D4172 showed improved tribological performance. The coefficient of friction for $\mathrm{SiO}_{2}$ nanolubricant showed $15 \%$ to $25 \%$ decrease in COF. The nanoparticles of graphite showed $\sim 15 \%-18 \%$ decrement in COF. The nanoparticles of $\mathrm{Cu}$ and $\mathrm{CuO}$ showed $\sim 9 \%-20 \%$ and $\sim 1.5 \%$ to $17 \%$ reduction in COF respectively, whereas the nanoparticle of $\mathrm{WS}_{2}$ showed $\sim 13 \%-$ $21 \%$ decrease in COF.

There was a significant reduction in the wear scar diameter recorded when measured by optical microscope. In case of $\mathrm{SiO}_{2}$ nanolubricant WSD decreased by $\sim 50 \%$ to 59\%. The graphite nanolubricant showed $\sim 45 \%-57 \%$ decrement in WSD. $\mathrm{Cu}$ and $\mathrm{CuO}$ nanolubricant showed $\sim 33 \%-49 \%$ and $\sim 13 \%$ to $28 \%$ reduction in WSD respectively whereas the $\mathrm{WS}_{2}$ nanolubricant showed $~ 17 \%-26 \%$ decrease in WSD.

The extreme pressure analysis was conducted according to ASTM- DIN 51350-02. There was a significant increase in the weld load in the case of nanolubricants which indicated the improved extreme pressure performance of the nanolubricant. The percentage increment in the weld load for $\mathrm{Cu}$ nanolubricant $\mathrm{SiO}_{2}$ nanolubricant, $\mathrm{WS}_{2}$ nanolubricant, $\mathrm{CuO}$ nanolubricant and Graphite nanolubricant obtained $~ 22 \%, 11 \%, 27 \%, 29 \%$ and 19\% respectively.

\section{ACKNOWLEDGEMENT}

The Author is thankful to CSIR for its financial support.

\section{REFERENCES}

1. Kumar Dubey M, Bijwe J, Ramakumar SSV. PTFE based nano-lubricants. Wear. 2013;306(1-2):80-88.

2. Erdemir A. Review of engineered tribological interfaces for improved boundary lubrication. Tribol Int. 2005;38(3):249-256.

3. Mathew J, Joy J, George SC. Potential applications of nanotechnology in transportation: A review. J King Saud Univ - Sci. 2018;(March).

4. Asrul M, Zulkifli NWM, Masjuki HH, Kalam MA. Tribological properties and lubricant mechanism of nanoparticle in engine oil. Procedia Eng. 2013;68:320-325.

5. Shahnazar S, Bagheri S, Abd Hamid SB. Enhancing lubricant properties by nanoparticle additives. Int J Hydrogen Energy. 2016;41(4):3153-3170.

6. Wu YY, Tsui WC, Liu TC. Experimental analysis of tribological properties of lubricating oils with nanoparticle additives. Wear. 2007;262(7-8):819-825.

7. Alves SM, Barros BS, Trajano MF, Ribeiro KSB, Moura E. Tribological behavior of vegetable oil-based lubricants with nanoparticles of oxides in boundary lubrication conditions. Tribol Int. 2013;65:28-36.

8. Tang Z, Li S. A review of recent developments of friction modifiers for liquid lubricants (2007-present). Curr Opin Solid State Mater Sci. 2014;18(3):119-139.

9. Lopez, J., Aguirre-Contreras, W. R., Gómez, M. E., \& ZAMBRANO, G. (2017). Zn concentration influence on the structure, morphology and magnetic properties of Co (1-X) ZnxFe2O4 nanoparticles in ferrofluids. IASET, 6, 47-60. 
10. Hernández Battez A, González R, Felgueroso D, et al. Wear prevention behaviour of nanoparticle suspension under extreme pressure conditions. Wear. 2007;263(7-12 SPEC. ISS.):1568-1574.

11. Padgurskas J, Rukuiza R, Prosyčevas I, Kreivaitis R. Tribological properties of lubricant additives of Fe, Cu and Co nanoparticles. Tribol Int. 2013;60:224-232.

12. Dai W, Kheireddin B, Gao H, Liang H. Roles of nanoparticles in oil lubrication. Tribol Int. 2016;102:88-98.

13. Tarasov S, Kolubaev A, Belyaev S, Lerner M, Tepper F. Study of friction reduction by nanocopper additives to motor oil. Wear. 2002;252(1-2):63-69.

14. Wang S, Han S, Xin G, et al. High-quality graphene directly grown on Cu nanoparticles for Cu-graphene nanocomposites. Mater Des. 2018; 139:181-187.

15. Yu HL, Xи Y, Shi PJ, et al. Characterization and nano-mechanical properties of tribofilms using Cu nanoparticles as additives. Surf Coatings Technol. 2008; 203(1-2):28-34.

16. Huang HD, Tu JP, Gan LP, Li CZ. An investigation on tribological properties of graphite nanosheets as oil additive. Wear. 2006;261(2):140-144.

17. Chaudhary S, Singh RC, Chaudhary R. Experimental Investigation of Influence of $\mathrm{SiO}_{2}$ Nanoparticles on the Tribological and Rheological properties of 15W40 Lubricating Oil. Int J Eng Technol. 2017;9(6):4307-4314.

18. Tao C, Wang B, Barber GC, Schall JD, Lan H. Tribological behaviour of SnO $\mathrm{O}_{2}$ nanoparticles as an oil additive on brass. Lubr Sci. 2018; (January):1-9.

19. Guo J, Barber GC, Schall DJ, Zou Q, Jacob SB. Tribological properties of ZnO and $\mathrm{WS}_{2}$ nanofluids using different surfactants. Wear. 2017;382-383(March):8-14.

20. Peña-Parás L, Taha-Tijerina J, Garza L, Maldonado-Cortés D, Michalczewski R, Lapray C. Effect of $\mathrm{CuO}$ and $\mathrm{Al}_{2} \mathrm{O}_{3}$ nanoparticle additives on the tribological behavior of fully formulated oils. Wear. 2015; 332-333:1256-1261. oi:10.1016/j.wear.2015.02.038

21. Hernández Battez A, Viesca JL, González R, Blanco D, Asedegbega E, Osorio A. Friction reduction properties of a CuO nanolubricant used as lubricant for a NiCrBSi coating. Wear. 2010; 268(1):325-328. 
